\title{
Antimicrobial resistance situation in animal health of Bangladesh
}

\author{
Md. Al Amin ${ }^{1}$, M. Nazmul Hoque ${ }^{2}$, Amam Zonaed Siddiki ${ }^{3}$, Sukumar Saha ${ }^{4}$ and Md. Mostofa Kamal ${ }^{10}$ \\ 1. Quality Control Laboratory, Department of Livestock Services, Savar, Dhaka-1341, Bangladesh; 2. Department of \\ Gynecology, Obstetrics and Reproductive Health, Faculty of Veterinary Medicine and Animal Science, Bangabandhu \\ Sheikh Mujibur Rahman Agricultural University, Gazipur-1706, Bangladesh; 3. Department of Pathology and Parasitology, \\ Chattogram Veterinary and Animal Sciences University, Chattogram, Bangladesh; 4. Department of Microbiology and \\ Hygiene, Bangladesh Agricultural University, Mymensingh-2202, Bangladesh. \\ Corresponding author: Md. Mostofa Kamal, e-mail: mostofa.kamal.phd@gmail.com \\ Co-authors: MAA: alamin_magura@yahoo.com, MNH: nazmul90@bsmrau.edu.bd, AZS: zsiddiki@gmail.com, \\ SS: sukumar.saha@bau.edu.bd
}

Received: 23-08-2020, Accepted: 12-11-2020, Published online: 19-12-2020

doi: www.doi.org/10.14202/vetworld.2020.2713-2727 How to cite this article: Al Amin M, Hoque MN, Siddiki AZ, Saha S, Kamal MM (2020) Antimicrobial resistance situation in animal health of Bangladesh, Veterinary World, 13(12): 2713-2727.

\begin{abstract}
Antimicrobial resistance (AMR) is a crucial multifactorial and complex global problem and Bangladesh poses a regional and global threat with a high degree of antibiotic resistance. Although the routine application of antimicrobials in the livestock industry has largely contributed to the health and productivity, it correspondingly plays a significant role in the evolution of different pathogenic bacterial strains having multidrug resistance (MDR) properties. Bangladesh is implementing the National Action Plan (NAP) for containing AMR in human, animal, and environment sectors through "One Health" approach where the Department of Livestock Services (DLS) is the mandated body to implement NAP strategies in the animal health sector of the country. This review presents a "snapshot" of the predisposing factors, and current situations of AMR along with the weakness and strength of DLS to contain the problem in animal farming practices in Bangladesh. In the present review, resistance monitoring data and risk assessment identified several direct and/or indirect predisposing factors to be potentially associated with AMR development in the animal health sector of Bangladesh. The predisposing factors are inadequate veterinary healthcare, monitoring and regulatory services, intervention of excessive informal animal health service providers, and farmers' knowledge gap on drugs, and AMR which have resulted in the misuse and overuse of antibiotics, ultimate in the evolution of antibiotic-resistant bacteria and genes in all types of animal farming settings of Bangladesh. MDR bacteria with extreme resistance against antibiotics recommended to use in both animals and humans have been reported and been being a potential public health hazard in Bangladesh. Execution of extensive AMR surveillance in veterinary practices and awareness-building programs for stakeholders along with the strengthening of the capacity of DLS are recommended for effective containment of AMR emergence and dissemination in the animal health sector of Bangladesh.
\end{abstract}

Keywords: animal health, antibiotic-resistant, antimicrobial resistance, bacteria, veterinary.

\section{Introduction}

Microorganisms are among the man's best friends and also worst foes. Antimicrobial agents have been extremely important cornerstones of modern medicine in food animal production since the last half of the previous century. Antimicrobials have contributed considerably to the prevention and treatment of infectious diseases in livestock, and some of them have played a very important role in the promotion of animal growth and feed efficiency [1,2]. Antimicrobial resistance (AMR) evolves as a natural consequence of antimicrobial usage (AMU) in multiple sectors such as human health, animal health and animal production, aquaculture, and agriculture [3]. It is considered as a crucial multifactorial and complex global problem

Copyright: Al Amin, et al. Open Access. This article is distributed under the terms of the Creative Commons Attribution 4.0 International License (http://creativecommons.org/licenses/ by/4.0/), which permits unrestricted use, distribution, and reproduction in any medium, provided you give appropriate credit to the original author(s) and the source, provide a link to the Creative Commons license, and indicate if changes were made. The Creative Commons Public Domain Dedication waiver (http:// creativecommons.org/publicdomain/zero/1.0/) applies to the data made available in this article, unless otherwise stated. because of the rapid emergence and spread of resistant bacteria and associated antibiotic-resistant genes (ARGs) among humans, animals, and the environment [4]. AMR leads to increased morbidity, mortality, disease burden, healthcare expenditure, and reduced livelihoods. It is estimated that an uncontained AMR problem will cause 300 million human deaths globally along with 100 trillion US\$ financial losses and $11 \%$ fall in livestock productions by $2050[5,6]$. The direct negative impact of AMR in the animal sector is the production losses which ultimately result in reduced food security. Developing countries are more vulnerable to AMR due to inappropriate and overuse of antibiotics, poor quality drugs, non-human use of antibiotics, inadequate drug monitoring and surveillance system, lack of awareness of AMR, and poverty [7].

Terrestrial and aquatic food-animal production industries are expanding rapidly to meet the increasing demand for animal-source nutrition worldwide. This expansion is comparatively greater in low-and middle-income countries (LMICs) than in high-income countries. Rising demand for animal-source nutrition in LMICs is working as driving force for shifting of 
the small-scale animal farming systems to intensive, large-scale, and specialized commercialization. Nontherapeutic use of antimicrobials for prevention and control of disease or as antimicrobial growth promoters (AGP) are common practices in intensive farm-animal production systems [8]. Use of AGPs at subtherapeutic doses in farm animals exerts selective pressure on circulating beneficial or commensal bacteria which ultimately accelerates the development of AMR [9]. Spill-over of the antibiotic residues, antibiotic-resistant bacteria, and ARGs from the animal farming systems to the surrounding environment and humans are creating a potential public health hazard worldwide [10]. In addition, the expansion of resistant clones, resistome (total resistance to antibiotics and heavy metals), and antibiotic-resistant (ABR) determinants among the animal, human, and environment-associated microbiomes have the potential to alter bacterial population genetics, thereby modifying the structure, and eventually the productivity of microbiomes where antibiotic-resistant bacteria can expand [11].

Bangladesh is a developing country in the Southeast Asian region. The livestock sector of Bangladesh is endowed with 403 million terrestrial animals, which shares about $1.47 \%$ of the gross domestic product to the national economy. This sector is also providing full-time and part-time employment to $20 \%$ and $50 \%$ people of the country, respectively [12]. Both poultry and food-animal farming systems in Bangladesh are diversified from household small farms to medium and large-scale commercial farms $[13,14]$. Due to the absence of adequate government animal healthcare system, farm owners mostly depend on informal and unqualified healthcare providers for the treatment of their animals. Therefore, irrationally prescribed and easy access to antibiotics leads to misuse, abuse, suboptimal, or overuse of these drugs in farms [13]. Moreover, antibiotics are also used as prophylactic and sometimes as growth promoters, specifically in large-scale commercial farms of Bangladesh [9]. The irrational, suboptimal, or overuse of antibiotics has resulted in the evolution of different species of pathogenic and zoonotic ABR bacteria in animal farming settings of Bangladesh [15-18]. Unhygienic animal husbandry practices in Bangladesh are creating an important risk factor for disseminating these pathogenic and zoonotic ABR bacteria into humans and the environment $[17,19]$.

The World Health Organization (WHO) endorsed a Global Action Plan (GAP) in 2015 based on "One Health" approach for combatting the emerging global threat from AMR [20]. The Food and Agriculture Organization of the United Nations (FAO) and the World Organization for Animal Health (OIE) also developed complementary plans and strategies for the same purpose [9]. In alignment with the WHO GAP guidelines, Bangladesh formulated and approved a National Action Plan (NAP) 2017-2022 for containment of AMR in human, animal, and environment sectors. For successful implementation of NAP, concerted and coordinated actions across the sectors are necessary. For this, detailed information on the current AMR situation in the human, animal, and environment sectors of Bangladesh is a prerequisite [20]. The Department of Livestock Services (DLS), Government of Bangladesh is the mandated body to formulate and execute a surveillance program on AMR and implement NAP strategies in the animal health sector of the country. Although the patterns and extent of AMR development in the animal-borne pathogens of Bangladesh have been reported in some studies [8,18,19,21,22], DLS has not yet looked deep into the matter. Before launching an AMR surveillance program in animal health sector of Bangladesh, it is utmost necessary to understand the knowledge gaps by analyzing nature and extent of the problem. The role of concerned regulating authorities (DLS), and registered veterinary practitioners for implementation of policies for antibiotic stewardship to seize the rising AMR threats is also a fundamental need. In light of emerging aspects of AMR, the present review is, therefore, aimed to fill up the knowledge gaps by reviewing previous studies on the AMR situation in the animal health sector of Bangladesh.

\section{Literature review}

To prepare this review, we conducted a literature review on the AMR situation in the animal health sector of Bangladesh and across the globe from Google Scholar, PubMed, ResearchGate, and Crossref databases. First, we focused the introductory section on the background of AMR situation worldwide, its impacts on livestock and public health sectors, the possible source of AMR in livestock, and current trends in antibiotic usage in Bangladesh. The databases were searched using the term "AMR situation in Bangladesh" with alternative terms "AMR pathogens in animal sector of Bangladesh;" "AMR bacteria in animal sector of Bangladesh;" "AMR bacteria in poultry sector of Bangladesh;" and "AMR bacteria in farm animals of Bangladesh." "Antibiotic-resistant" or "antimicrobial-resistant" terms were also used as alternative to "AMR." Searches were filtered for research or review articles published in the English language from January 2011 to June 2020. Grey materials/unpublished documents were searched using Google and retrieved from the relevant institutional websites. Studies conducted on the AMR situation in humans, agriculture, aquaculture, or the environment were excluded considering irrelevant to the present study. The articles directly assessed husbandry and medication practices along with antibiotic-resistant bacteria or genes in food-producing or non food-producing animals of Bangladesh were included for general review. The literatures described "in place" institutional and policy structures of DLS to combat AMR burden in Bangladesh were also considered. 
The key findings (first authors, year of publication, animal farm type with geographical location, pathogen type, spectrum of resistance with classes of antibiotics, and resistant genes) related to this study were retrieved from the articles. Extracted data were analyzed at $95 \%$ confidence level using IBM SPSS Statistics 20 software. To find out the associations and level of significance among different variables, we used Pearson Chi-square test.

\section{Results}

We identified a total of 44 peer-reviewed articles that contained information relevant to the present study. Of these, five articles (Table-S1) reported medication patterns in veterinary practices, 23 articles (Table-S2) reported ABR bacteria and genes prevalent in poultry sector, and 13 articles (Table-S3) reported those prevalent in dairy and other animal sector and three articles (Table-S4) described "in place" institutional and policy structures of DLS to combat ABR burden in Bangladesh. The findings from the review of the selected articles are described below according to the key themes of the study.

\section{Medication patterns in veterinary practices of Bangladesh}

In rural Bangladesh, $57.7 \%$ of households own livestock, including large animals (cattle and buffalo), small ruminants (sheep and goats), and poultry (back yard and commercial). Government veterinary healthcare providers rarely $(9.7 \%)$ visit these households. In the absence of adequate veterinary healthcare service, animal owners in rural areas avail low-cost animal health care from pharmacies and unlicensed village doctors $(82.5 \%)$. In addition to feed additives, animal owners use antibiotics, largely at suboptimal doses on suggestions of the informal animal healthcare providers [13]. The prescribing and dispensing of antibiotics in animal sectors of Bangladesh are neither lawfully regulated nor their use lawfully audited [20].

Medication practices in poultry sector of Bangladesh are very complex. In commercial poultry farms, especially in small and medium-scale settings the poultry and feed dealers are the main influencers on antibiotic usage. The poultry and feed dealers provide financial support and farming related technical information to the farmers to initiate and operate their farms. Thereby, the farmers become obliged to buy poultry chicks, feed, and medicine from the dealers. Sales representatives of the pharmaceutical companies are another influencing group in poultry farming systems. In addition to providing product information, sales representatives also provide treatment advice directly to the farmers. Recently, qualified veterinary doctors appointed by the hatcheries, feed companies and pharmaceutical companies are providing poultry management and treatment services to the farmers [23].

The study revealed that the incidence of active infections, high mortality rates, and an aspiration to prevent disease were the major drivers of antimicrobials use in poultry farms. Broiler farmers use antibiotics for therapeutic purposes, for prophylaxis, and also for growth promotion. The majority of the farmers $(>60 \%)$ use antibiotics without any prescription from veterinary doctors [24]. Layer farmers are also not aware of prudent use of antibiotics. They use antibiotics to prevent egg production fall, for treatment purposes and also for prophylaxis in suboptimal doses. Most of the small-scale layer farmers $(94.16 \%)$ use antibiotics without prescription and do not maintain the withdrawal period of drugs [25]. Besides the farms, the poultry meat sellers in live bird markets (LBMs) also use different types of antibiotic to prevent unwanted mortality [26].

The small and medium-scale poultry farmers apply multiple antibiotics, even banned antibiotics to poultry throughout the production cycle following the suggestions of the poultry dealers [23]. As many as 19 and ten different types of antibiotic usage have been recorded in the broiler and layer farms, respectively. The most commonly used antibiotics in both types of farming systems are ciprofloxacin, ampicillin, amoxicillin, trimethoprim, oxytetracycline, tylosin tartrate, tiamulin, norfloxacin, enrofloxacin, doxycycline, and colistin sulfate [24,25].

\section{Antibiotic-resistant bacteria reported in the poultry sector}

A total of eight ABR bacterial species were reported in layer, broiler, backyard poultry, ducks, pigeons, and quails in nine different districts of Bangladesh (Table-1) [8,15,16,22,27-44]. ABR Escherichia coli was identified in different types of birds from both conventional and unconventional farming systems in different areas of Bangladesh. Newly hatched broiler and layer chicks in hatcheries of Gazipur district experienced navel infection with $\mathrm{ABR} E$. coli with a higher degree of resistance against ampicillin (80-100\%), amoxicillin (60-100\%), and kanamycin (80\%) [27]. MDR E. coli isolates recovered from dead, sick, and apparently healthy broilers of Gazipur, Mymensingh, and Chattogram districts showed a varying magnitude of resistance against tetracycline (45.5-100\%), ampicillin (100\%), trimethoprim-sulfamethoxazole (26.7-94.59\%), nalidixic acid (25.7-91.89\%), ampicillin (25.7\%), streptomycin (20.8\%), and ciprofloxacin [28-30]. Of these, tetracycline, ampicillin, nalidixic acid, and trimethoprim-sulfamethoxazole were the antibiotics against which $E$. coli from all the broiler sources developed resistance. All $E$. coli isolates from apparently healthy broilers of LBMs in Chattogram city carried bla ${ }_{\text {TEM }}$, tetA, and Sul2 multidrug-resistant genes. Likewise, MDR E. coli was also reported in layer chickens with resistance against the same type of antibiotics as in broiler from different areas of Bangladesh $[8,29]$. Ubiquitous dissemination of MDR E. coli with resistance against tetracycline $(100 \%)$, fluoroquinolone $(85 \%)$, sulfamethoxazole-trimethoprim $(85 \%)$, aminoglycosides (71\%), and nitrofurantoin $(21 \%)$ 
Table-1: Antibiotic-resistant bacterial species reported in poultry and other birds of Bangladesh from January 2011 to June 2020.

\begin{tabular}{|c|c|c|c|c|}
\hline $\begin{array}{l}\text { Name of } \\
\text { bacteria }\end{array}$ & Source & Area (District) & $\begin{array}{l}\text { Spectrum of antibiotic } \\
\text { resistance }(\%)\end{array}$ & References \\
\hline E. coli & $\begin{array}{l}\text { Apparently healthy, sick } \\
\text { and dead broiler, layer and } \\
\text { domestic birds; ducks, and } \\
\text { geese; apparently healthy } \\
\text { Japanese quails; broiler } \\
\text { meat; newly hatched } \\
\text { chicks from broiler and } \\
\text { layer flocks }\end{array}$ & $\begin{array}{l}\text { Dhaka, Gazipur, } \\
\text { Mymensingh, } \\
\text { Chattogram, } \\
\text { Rajshahi, Sylhet, } \\
\text { Sherpur }\end{array}$ & 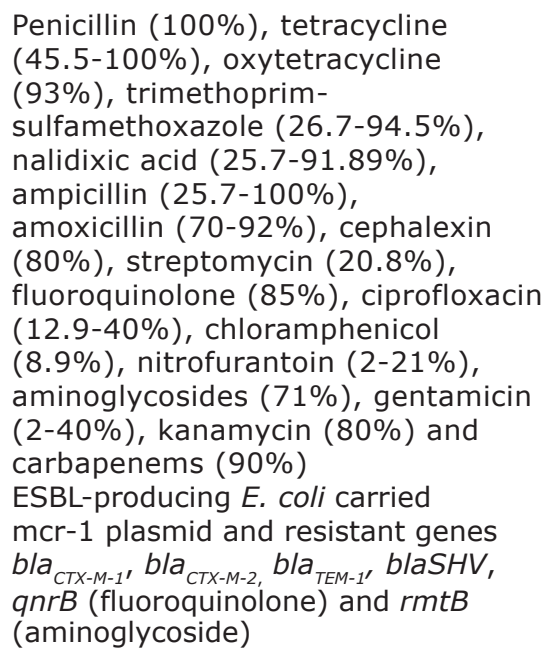 & {$[8,15,27-37]$} \\
\hline Salmonella spp. & $\begin{array}{l}\text { Apparently healthy, sick } \\
\text { and dead layer and broiler } \\
\text { chickens; litter and feed } \\
\text { samples from broiler } \\
\text { farms; apparently healthy } \\
\text { pigeons of LBMs, farms } \\
\text { and villages; Apparently } \\
\text { healthy Japanese quails; } \\
\text { Poultry slaughterer's } \\
\text { hand and poultry residual } \\
\text { container of poultry- } \\
\text { slaughter houses; broiler } \\
\text { meat; newly hatched } \\
\text { chicks from broiler and } \\
\text { layer flocks }\end{array}$ & $\begin{array}{l}\text { Dhaka, Gazipur, } \\
\text { Sherpur, } \\
\text { Mymensingh and } \\
\text { Chattogram }\end{array}$ & 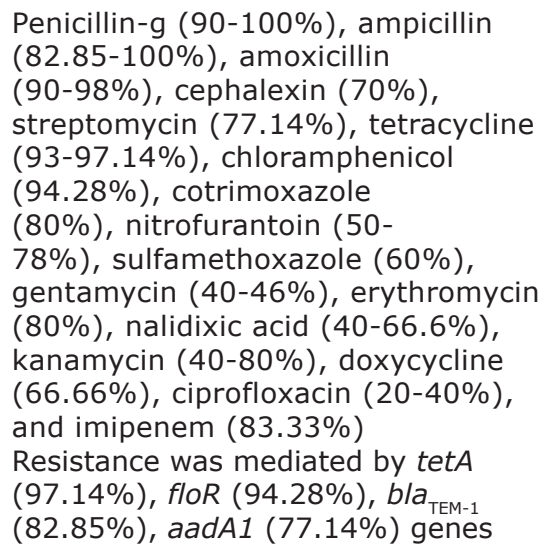 & $\begin{array}{c}{[8,16,22,27,32,} \\
36,38-40]\end{array}$ \\
\hline $\begin{array}{l}\text { Enterobacter } \\
\text { spp. }\end{array}$ & Layer poultry & Dhaka & $\begin{array}{l}\text { Penicillin (100\%), rifampicin } \\
(100 \%) \text {, ampicillin }(94.4 \%) \text {, } \\
\text { clindamycin }(94.4 \%) \text {, erythromycin } \\
(94.4 \%) \text {, vancomycin }(88.9 \%) \text {, } \\
\text { sulfonamides }(72.2 \%) \text {, imipenem } \\
(66.6 \%) \text {, streptomycin }(55.6 \%) \text {, } \\
\text { nitrofurantoin }(33.3 \%) \text {, doxycycline } \\
(33.3 \%) \text {, tetracyclines }(33.3 \%) \text {, and } \\
\text { gentamicin }(5.6 \%)\end{array}$ & [41] \\
\hline C. portucalensis & Layer poultry & Narayanganj & $\begin{array}{l}\text { Resistant to polymyxin, } \\
\text { sulfonamide, tetracycline, } \\
\text { aminoglycoside, fluoroquinolones, } \\
\text { and macrolide antimicrobial groups. } \\
\text { Complete genome harbored } \\
\text { following } 8 \text { AMR genes: dfrA12 } \\
\text { (trimethoprim); sul1 and sul2 } \\
\text { (sulfonamide); mph (A) (macrolide); } \\
\text { tet (A) (tetracycline); qnrS1 } \\
\text { and qnrB13 (fluoroquinolone); } \\
\text { blaCMY-39 ESBL, blaTEM-176 (non- } \\
\text { ESBL) and aadA2, aph (30)-Ia, aph } \\
\text { (300)-Ib, aph (30)-IC, aph (30)-Id, } \\
\text { strA, strB (aminoglycoside) }\end{array}$ & {$[42]$} \\
\hline $\begin{array}{l}\text { Pasteurella } \\
\text { spp.; Bacillus } \\
\text { spp. }\end{array}$ & $\begin{array}{l}\text { Apparently healthy } \\
\text { Japanese quails }\end{array}$ & Mymensingh & $\begin{array}{l}\text { Resistant to erythromycin, } \\
\text { sulfamethoxazole and tetracycline } \\
\text { (Quantitative data not available) }\end{array}$ & {$[32]$} \\
\hline $\begin{array}{l}\text { Staphylococcus } \\
\text { spp. }\end{array}$ & $\begin{array}{l}\text { Apparently healthy } \\
\text { Japanese quails; frozen } \\
\text { chicken rinse; newly } \\
\text { hatched chicks from } \\
\text { broiler and layer flocks }\end{array}$ & $\begin{array}{l}\text { Mymensingh, } \\
\text { Gazipur, } \\
\text { Chattogram }\end{array}$ & $\begin{array}{l}\text { Resistant to amoxicillin and ampicillin } \\
(100 \%) \text { and kanamycin }(100 \%), \\
\text { oxytetracycline }(100 \%) \text {, doxycycline } \\
(80 \%) \text {, and ciprofloxacin }(77.5 \%)\end{array}$ & {$[27,32,43]$} \\
\hline
\end{tabular}


Table-1: (Continued).

\begin{tabular}{|c|c|c|c|c|}
\hline $\begin{array}{l}\text { Name of } \\
\text { bacteria }\end{array}$ & Source & Area (District) & $\begin{array}{l}\text { Spectrum of antibiotic } \\
\text { resistance }(\%)\end{array}$ & References \\
\hline $\begin{array}{l}\text { Campylobacter } \\
\text { spp. }\end{array}$ & $\begin{array}{l}\text { Hatcheries, broiler farms, } \\
\text { and LBMs; broiler meat }\end{array}$ & $\begin{array}{l}\text { Mymensingh, } \\
\text { Gazipur, and } \\
\text { Tangail }\end{array}$ & 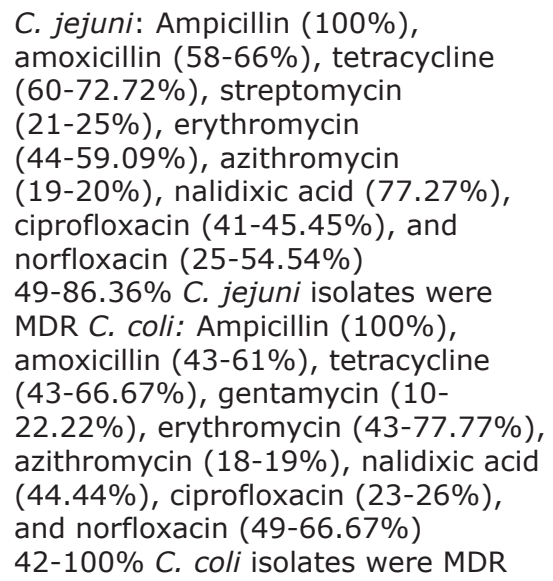 & {$[21,44]$} \\
\hline
\end{tabular}

$\mathrm{MDR}=$ Multidrug resistance, LBMs=Live bird markets, $E$. coli=Escherichia coli, ESBL=Extended-spectrum $\beta$-lactamase, C. portucalensis=Citrobacter portucalensis, C. jejuni=Campylobacter jejuni, C. coli=Campylobacter coli

was identified in backyard poultry of Bangladesh. These extended-spectrum $\beta$-lactamases (ESBL) producing $E$. coli from backyard poultry carried $m c r-1$ plasmid and resistant genes $b l a_{\text {CTX-M-group-1 }}, b l a_{\text {TEM }}-1$ (ESBL), qnrB (fluoroquinolone), and $r m t B$ (aminoglycoside) [15]. MDR and ESBL-producing E. coli was also found prevalent in ducks, geese, quails, and pigeons from unconventional commercial farms and LBMs [31-33]. The E. coli isolates from the birds of unconventional farms were resistant against tetracycline $(90 \%)$, amoxicillin $(70 \%)$, sulfamethoxazole $(90 \%)$, and other antibiotics commonly used in broiler and layer farms. Besides the farming settings, alarmingly MDR and XDR E. coli with resistance against oxytetracycline (93\%), amoxicillin (91.9\%), ampicillin $(89.5 \%)$, trimethoprim-sulfamethoxazole $(88.4 \%)$, tetracycline $(84.9 \%)$, and carbapenems $(89.6 \%)$ were reported in frozen chicken meats from various parts of Bangladesh. ESBL genes $b l a_{\mathrm{TEM}}, b l a_{\mathrm{SHV}}$, and $b l a_{\mathrm{CTX}-\mathrm{M}-2}$ were prevalent in these MDR and XDR E. coli [34].

Multidrug-resistant (MDR) Salmonella species were reported from various types of birds reared in different farming systems. Day-old chicks, dead, sick, and even apparently healthy layer birds harbored MDR Salmonella with resistance against penicillin-G (90$100 \%)$, ampicillin (100\%), amoxicillin (98-100\%), tetracycline $(93 \%)$, nitrofurantoin $(78 \%)$, sulfamethoxazole $(60 \%)$, gentamycin $(46 \%)$, and ciprofloxacin (20-40\%) [8,36,38,40]. MDR Salmonella spp. was also identified in cloacal swabs, litter, and feed samples of broiler farms with resistance against a range of antibiotics and the antibiotic resistance was carried by tetA $(97.14 \%)$, floR, bla $a_{\text {TEM-1 }}$, and aadAl (77.14\%) genes [16]. Two studies reported the dissemination of MDR Salmonella in unconventional farming systems. Apparently healthy quails and pigeons were found to carry MDR Salmonella with resistance against amoxicillin (90\%), ampicillin (80\%), erythromycin
$(80 \%)$, tetracycline $(60 \%)$, chloramphenicol $(40 \%)$, kanamycin (40\%), gentamicin (40\%), nalidixic acid $(40 \%)$, sulfamethoxazole $(30 \%)$, and ciprofloxacin $(20 \%)$ [32,39]. In LBM, broiler meat, poultry slaughterers' hand, and poultry residual containers harbored MDR Salmonella with the highest resistance to imipenem $(83.33 \%)[22,36]$. Salmonella from all of the poultry-associated sources has already developed resistance against a broad range of antibiotics, including ampicillin, amoxicillin, tetracycline, and gentamycin (Table-1).

MDR nosocomial opportunistic pathogen Enterobacter spp. were documented in layer poultry with resistance against a range of antibiotics used in both animals and humans [41]. Another potential human pathogen Citrobacter portucalensis from layer poultry also showed resistance against a wide range of antibiotics mediated by eight AMR genes in its genome [42]. Moreover, Pasteurella, Bacillus, and Staphylococcus species isolated from apparently healthy Japanese quails and newly hatched broiler and layer chicks showed resistance against commonly used antibiotics (Table-1). Foodborne pathogen Staphylococcus aureus which showed resistance against a number of antibiotics was identified in the frozen chicken rinse [43].

Reports on the prevalence of antimicrobial-resistant crucial foodborne pathogen Campylobacter from different areas of Bangladesh revealed the contamination of broiler meat with MDR Campylobacter jejuni and Campylobacter coli with varying degree of resistance against several antibiotics (Table-1). In addition, oxytetracycline, ciprofloxacin, and enrofloxacin residues were detected in the majority of broiler liver and meat samples, some of which had a concentration above the acceptable limit [21].

\section{Antibiotic-resistant bacteria prevalent in dairy and} other animals

Different species of ABR bacteria have been documented from dairy, goat, and wild animal sources 
in different areas of Bangladesh. MDR E. coli have been reported in cattle and goat of intensive and freerange farming systems as well as in milk of cows, milkers' hands, and different components of farm environment (Table-2). Along with resistance against antibiotics commonly used in veterinary practices, $E$. coli isolated from milk, milkers' hands, and farm environment carried tet $A$ and $S H V$ resistance genes and developed extreme resistance against azithromycin $(100 \%)$ which is recommended to use in humans only [17]. Milk of mastitis-affected cows was identified as another important source of MDR E. coli with resistance against ampicillin $(100 \%)$, amoxicillin $(30-100 \%)$, and streptomycin $(70-100 \%)[18,45]$. Besides E. coli, milk of mastitis-affected cows was also a source of antibiotic-resistant Bacillus, Streptococcus, Staphylococcus, Klebsiella, Enterobacter, and Shigella spp. which developed resistance against several antibiotics (Table-2) [17-19,45-54]. In a study of bovine subclinical mastitis milk, $S$. aureus isolates showed the highest resistance to oxytetracycline $(74.5 \%)$, followed by oxacillin $(55.9 \%)$, ciprofloxacin $(49.6 \%)$, amoxicillin $(42.0 \%)$, trimethoprim/sulfamethoxazole $(30.0 \%)$, and to a less extent to gentamicin $(17.9 \%)$, penicillin (11.0\%), and erythromycin (8.2\%) [46]. The disposal of farm waste directly into the environment contributes in the ABR bacteria pollution and ultimately poses a health hazard to both farm animals and humans [19].

MDR foodborne zoonotic pathogen Salmonella spp. carrying tetA and $S H V$ resistance genes were reported from cow dung, milk, milkers' hand, and dairy farm environment with resistance against a number of antibiotics such as erythromycin $(87.5 \%)$, tetracycline $(86.76 \%)$, oxytetracycline $(75.73 \%)$, and ertapenem (50\%) [17]. Dissemination of antibiotic-resistant Salmonella spp. even in wild Irrawaddy squirrels was identified. The wild Irrawaddy squirrels also harbored ABR E. coli, Staphylococcus, and Yersinia spp. All the antibiotic-resistant bacteria isolated from wild Irrawaddy squirrels showed resistance against amoxicillin, tetracycline, colistin sulfate, sulfamethoxazole-trimethoprim, and cephalexin [51].

Contamination of the animal originated food products by antibiotic-resistant bacteria with resistance against tetracycline $(100 \%)$, nalidixic acid $(100 \%)$, oxacillin $(100 \%)$, erythromycin $(53.33 \%)$, ciprofloxacin (40\%), doxycycline (26.66\%), and ampicillin (6.67\%) was also reported [54].

\section{Institutional and policy structures to combat AMR in the veterinary sector}

The state veterinary service of Bangladesh is provided through the DLS, Government of Bangladesh. DLS is providing veterinary service to the field level through its eight divisional, 64 district and 488 sub-district (Upazila) livestock offices. The veterinary hospital network of the country includes one central veterinary hospital, 64 district and 488 sub-district (Upazila) veterinary hospitals. In addition, there are nine metro veterinary hospitals to provide services in city areas. One to two registered veterinarians along with other supportive sub-technical personnel are deployed in each district, sub-district (Upazila) or metro veterinary hospitals [55]. The registered veterinarians provide animal healthcare services as well as engaged in monitoring and surveillance activities to ensure the prudent use of antimicrobials in the veterinary sector. In addition to veterinary hospitals, DLS has a sufficient number of laboratories for providing animal disease diagnostic supports to the field veterinarians and farmers. The laboratories are: One central disease investigation laboratory, eight field disease investigation laboratories, one quality control laboratory, and one veterinary public health and microbiology laboratory [55].

The Bangladesh government enacted "Fish Feed and Animal Feed Act, 2010" and "Animal Feed Rule, 2013" which prohibited the use of antibiotics in animal feed and restricted the use of colistin as a critically important antibiotic. These regulations empowered DLS to designate competent personnel for enforcing activities such as investigation, arrest, search, and seizure, prosecutions to prevent use of antibiotics in animal feed. Bangladesh is implementing the NAP for containing AMR in human, animal, and environment sectors through "One Health" approach where a coordinated effort from all implementing partners with strong commitment and participation are necessary for combating AMR in Bangladesh as well as to ensure one health. The NAP has assigned DLS to execute all necessary activities to achieve strategic objectives for containing AMR problems in veterinary practices. Although such activities are being performed by the DLS, there are still some policy gaps, including an explicit financing modality, specifications for antimicrobial stewardship in the veterinary sector, and rigorous operational, monitoring, and evaluation frameworks [6].

\section{Discussion}

The animal health system of Bangladesh is explicitly "pluralistic" involving unqualified healthcare providers and different influential groups at different stages $[13,23]$. The absence of adequate, specifically state veterinary healthcare, regulatory and monitoring services, and low financial capability of the farmers has created pavements for the unlicensed village doctors, poultry and feed dealers, and pharmaceutical sales representatives to influence over the animal farm owners to take their decisions. In addition, increased demand for animal-source protein and knowledge gap on animal diseases, drugs, and AMR burden have driven the farmers toward the misuse or overuse of antibiotics. The weak regulatory regimes for antimicrobial stewardship programs and multidimensional anomalies in the use antibiotics in veterinary practices have resulted in the emergence of AMR pathogens in animals of Bangladesh [20]. Similar risk 
Table-2: Antibiotic-resistant bacterial species reported in dairy and other animals of Bangladesh from January 2011 to June 2020.

\begin{tabular}{|c|c|c|c|c|}
\hline $\begin{array}{l}\text { Name of } \\
\text { bacteria }\end{array}$ & Source & Area (District) & $\begin{array}{l}\text { Spectrum of antibiotic } \\
\text { resistance }(\%)\end{array}$ & Reference \\
\hline E. coli & $\begin{array}{l}\text { Cattle of intensive and } \\
\text { free-range farming } \\
\text { systems; cow dung, milk, } \\
\text { milkers' hand wash, soil, } \\
\text { water, and vegetables of } \\
\text { dairy farms; milk from } \\
\text { mastitis affected cows; } \\
\text { feces of goats; wild } \\
\text { Irrawaddy squirrels }\end{array}$ & $\begin{array}{l}\text { Dhaka, } \\
\text { Mymensingh, } \\
\text { Chattogram, } \\
\text { Sirajganj, } \\
\text { Satkhira, Rajshahi, } \\
\text { Cox's bazar and } \\
\text { Bandarban }\end{array}$ & $\begin{array}{l}\text { Azithromycin (100\%), amoxicillin } \\
(60.26-100 \%) \text {, ampicillin }(65.38- \\
100 \%) \text {, cephalexin }(53.8 \%) \text {, } \\
\text { nalidixic acid }(86 \%), \text { tetracycline } \\
(89.44-100 \%) \text {, erythromycin }(83- \\
88.89 \%), \text { oxytetracycline }(78.89 \%) \text {, } \\
\text { sulfamethoxazole }(100 \%) \text {, and } \\
\text { ertapenem }(66.67 \%), \text { streptomycin } \\
(47.44-100 \%) \text { and gentamicin } \\
(37.18 \%) \text { tetA and SHV resistance } \\
\text { genes were prevalent among the } \\
\text { AMR } E \text {. coli isolates }\end{array}$ & {$[17,18,45,47-51]$} \\
\hline Salmonella spp. & $\begin{array}{l}\text { Cow dung, milk, milkers' } \\
\text { hand wash, soil, water, } \\
\text { and vegetables of dairy } \\
\text { farms; wild Irrawaddy } \\
\text { squirrels }\end{array}$ & $\begin{array}{l}\text { Mymensingh, } \\
\text { Cox's bazar and } \\
\text { Bandarban }\end{array}$ & $\begin{array}{l}\text { Amoxicillin }(42.6 \%) \text {, erythromycin } \\
(87.5 \%) \text {, tetracycline }(28.6- \\
86.76 \%) \text {, oxytetracycline }(75.73 \%) \\
\text { and ertapenem }(50 \%) \text {, colistin } \\
\text { sulfate }(28.6 \%) \text {, cephalexin }(71.4 \%) \\
\text { tetA and SHV resistance genes } \\
\text { were prevalent among the AMR } \\
\text { Salmonella isolates }\end{array}$ & {$[17,51]$} \\
\hline Bacillus spp. & $\begin{array}{l}\text { Milk from mastitis } \\
\text { affected cows }\end{array}$ & $\begin{array}{l}\text { Dhaka, } \\
\text { Chattogram, } \\
\text { Gazipur, } \\
\text { Mymensingh, } \\
\text { Sylhet, Satkhira, } \\
\text { Rajshahi }\end{array}$ & $\begin{array}{l}\text { Doxycycline, ampicillin, nalidixic } \\
\text { acid, and erythromycin }(60.0- \\
84.0 \%) \text {, streptomycin }(70-100 \%)\end{array}$ & {$[18,45,47,48]$} \\
\hline $\begin{array}{l}\text { Streptococcus } \\
\text { spp. }\end{array}$ & $\begin{array}{l}\text { Milk from mastitis affected } \\
\text { cows }\end{array}$ & $\begin{array}{l}\text { Mymensingh, } \\
\text { Rajshahi }\end{array}$ & $\begin{array}{l}\text { Resistant to streptomycin (70- } \\
100 \%) \text {, amoxicillin }(30-100 \%) \text {, and } \\
\text { ampicillin }(60-100 \%)\end{array}$ & [45] \\
\hline $\begin{array}{l}\text { Staphylococcus } \\
\text { spp. }\end{array}$ & $\begin{array}{l}\text { Milk from mastitis affected } \\
\text { cows; wild Irrawaddy } \\
\text { squirrels }\end{array}$ & $\begin{array}{l}\text { Dhaka, } \\
\text { Chattogram, } \\
\text { Gazipur, } \\
\text { Mymensingh } \\
\text { Satkhira, Rajshahi, } \\
\text { Cox's bazar and } \\
\text { Bandarban }\end{array}$ & $\begin{array}{l}\text { Amoxicillin }(42-100 \%) \text {, ampicillin } \\
(73-100 \%) \text {, streptomycin }(70- \\
100 \%) \text {, tetracycline }(30.8-88 \%), \\
\text { doxycycline }(73.0-88.0 \%), \\
\text { ciprofloxacin }(49.6 \%), \text { colistin } \\
\text { sulfate }(53.9 \%), \text { sulfamethoxazole- } \\
\text { trimethoprim }(30.8 \%) \text {, cephalexin } \\
(61.5 \%) ; \text { chloramphenicol, } \\
\text { ciprofloxacin, and nitrofurantoin } \\
(50.0-58.0 \%)\end{array}$ & {$[18,45-48,51]$} \\
\hline Yersinia spp. & Wild Irrawaddy squirrels & $\begin{array}{l}\text { Cox's bazar and } \\
\text { Bandarban }\end{array}$ & $\begin{array}{l}\text { Amoxicillin ( } 69.2 \%) \text {, tetracycline } \\
(46.2 \%) \text {, colistin sulfate }(53.9 \%) \text {, } \\
\text { sulfamethoxazole-trimethoprim } \\
(30.8 \%) \text {, cephalexin }(53.8 \%), \\
\text { ciprofloxacin }(7.7 \%) \text {, gentamycin } \\
(15.4 \%)\end{array}$ & {$[51]$} \\
\hline $\begin{array}{l}\text { Klebsiella, } \\
\text { Enterobacter, } \\
\text { and Shigella }\end{array}$ & $\begin{array}{l}\text { Milk from mastitis } \\
\text { affected cows }\end{array}$ & $\begin{array}{l}\text { Dhaka, } \\
\text { Mymensingh, } \\
\text { Chattogram, } \\
\text { Gazipur, Sylhet }\end{array}$ & $\begin{array}{l}\text { Doxycycline, nalidixic acid, } \\
\text { tetracycline, and ampicillin ( } 70.0- \\
100.0 \%) ; \text { ciprofloxacin, gentamicin, } \\
\text { nitrofurantoin, and chloramphenicol } \\
(30.0-70.0 \%) \text {. }\end{array}$ & {$[18]$} \\
\hline $\begin{array}{l}\text { Pseudomonas } \\
\text { aeruginosa }\end{array}$ & Pus from abscess of cattle & Mymensingh & $\begin{array}{l}\text { Resistant to ampicillin, } \\
\text { oxytetracycline, tetracycline and } \\
\text { amoxicillin }\end{array}$ & {$[52]$} \\
\hline Vibrio Cholerae & $\begin{array}{l}\text { Milk from cows, water } \\
\text { and feces from farm } \\
\text { environment }\end{array}$ & Mymensingh & $\begin{array}{l}\text { Resistant to erythromycin }(95.23 \%) \text {, } \\
\text { azithromycin }(76.9 \%) \text { and ampicillin } \\
(52.38 \%)\end{array}$ & {$[53]$} \\
\hline $\begin{array}{l}\text { Bacterial species } \\
\text { not identified }\end{array}$ & $\begin{array}{l}\text { Feces and waste-water of } \\
\text { dairy farm and veterinary } \\
\text { clinics }\end{array}$ & Dhaka & $\begin{array}{l}\text { Bacterial isolates were significantly } \\
\text { resistant to three aminoglycoside } \\
\text { antibiotics-gentamycin, kanamycin } \\
\text { and streptomycin }\end{array}$ & [19] \\
\hline $\begin{array}{l}\text { Bacterial species } \\
\text { not identified }\end{array}$ & $\begin{array}{l}\text { Bovine livers sold at retail } \\
\text { meat shops }\end{array}$ & Chattogram & $\begin{array}{l}\text { Tetracycline }(100 \%), \text { nalidixic } \\
\text { acid }(100 \%), \text { oxacillin }(100 \%), \\
\text { erythromycin }(53.33 \%), \\
\text { ciprofloxacin }(40 \%), \text { doxycyclin } \\
(26.66 \%) \text { and ampicillin }(6.67 \%)\end{array}$ & {$[54]$} \\
\hline
\end{tabular}

E. coli=Escherichia coli 
factors behind the emergence of AMR burden were previously reported in Southeast Asian and other LMIC [3,9].

The aforesaid risk factors have resulted in the emergence of distinguished AMR bacteria in different animal farming settings of Bangladesh (Tables-1 and 2). The circulations of AMR pathogens from January 2011 to June 2020 were reported by small-scale studies indeed carried out in different universities and covered only 13 districts out of 64 in the country. Therefore, the AMR situation in veterinary practices in most areas of the country remained unveiled. Even though, these small-scale studies reported a good number of AMR pathogens circulating in animals of Bangladesh with antibiogram profiling for each. For antibiogram profiling, most of the studies used culture and disk diffusion technique, although several studies incorporated molecular AMR genotyping tools [15-17,31]. Two studies adopted cutting edge technology - whole metagenome sequencing (WMS) along with disk diffusion technique to characterize the resistome of the microbiome of the clinical sample $[18,42]$. WMS approach coupled with bioinformatics is increasingly replacing conventional culture-dependent systems because of its capability to assessing the clonal diversity and similarity among human and animal bacterial isolates and providing greater insights into the shared resistance genes [4].

Insignificant difference $(p=0.157$, Pearson Chi-square test) between poultry and dairy farming settings with respect to AMR pathogen emergence deciphers that both types of farms are equally contributing to the emergence of AMR burden in Bangladesh. Of the AMR pathogens, MDR E. coli was the most abundant and Salmonella was the second most (Tables-1 and 2). The underlying causes may be their ubiquitous distribution and inclusion of $E$. coli as an indicator organism in most of the AMR studies [56]. High prevalence of MDR $E$. coli was also reported from poultry farms of Vietnam, India, and Ecuador [4]. Other than the organized poultry and dairy farming practices, the emergence of MDR E. coli, Salmonella, Staphylococcus, Pasteurella, and Bacillus spp. in unconventional poultry farming systems or MDR $E$. coli, Salmonella, and Yersinia species in small wild fauna are indicative of the high magnitude of the AMR burden in Bangladesh (Tables-1 and 2).

Among the MDR pathogens, E. coli, Salmonella, Enterobacter, Staphylococcus, and Campylobacter spp. are potential zoonotic pathogens creating direct human health hazards [57]. Unhygienic animal husbandry practices such as sharing of houses and water bodies with animals, disposal of farm wastes directly in the environment, along with poor personal hygiene of farm workers, and animal dwellers are exacerbating the risks of AMR dissemination in humans $[13,58]$. Moreover, contamination of broiler meat, frozen chicken meat, bovine meat, and milk, as well as the animal, originated food products with
MDR bacteria, bringing the consumers closer to AMR hazards $[17,18,44,54]$.

The reported MDR pathogens developed resistance against number of antibiotics commonly recommended to use in animal health [13,24] (Tables-1 and 2). The animal health is being directly affected by narrow-downed treatment scope resulted from high magnitude of AMR problem. Surprisingly, MDR E. coli, Salmonella, and Enterobacter isolated from both poultry and dairy also showed resistance against imipenem, azithromycin, and colistin sulfate recommended for human use only and strictly prohibited to use in animal health $[17,22,41]$. This may be due to use of these antibiotics in animal health or transmission of AMR genes from human to animal pathogens. The unethical use of antibiotics reserved for humans in veterinary practices will pose public health to a potential risk. The emergence of ESBL-producing genes and colistin-resistant $m c r-1$ gene in ARB is alarming considering their potentiality to reduce the efficacy of last-resort antibiotics $[15,34]$.

Although the DLS, Bangladesh has sufficiently extended its institutional establishments (veterinary hospitals and laboratories) throughout the country, these institutions are deficient in manpower, disease diagnostic facilities, and logistics. The veterinarians deployed in each of these hospitals are vested in providing service to a large jurisdiction which is practically impossible. Less availability of the state veterinary service often becomes a cause of "dissatisfaction" among the farmers [13]. Moreover, inadequate numbers of competent veterinarians at field level squeeze the scope of proper monitoring, surveillance, and AMR stewardship activities on AMU to containing this burden. The scarcity of proper animal disease diagnostic facilities in veterinary hospitals and laboratories is resulting in presumptive and wrong antimicrobial treatments; ultimately in AMR development. Despite some gaps, the policy structure of DLS is quite sufficient for combating AMR in veterinary practices of Bangladesh [6].

There is no alternative to formulating and executing an extensive and pragmatic surveillance program to unveil the real picture of the AMR situation in veterinary practices of Bangladesh. Scientific research to improve understanding of the risk factors for the emergence and spread of AMR is required to design evidence-based appropriate interventions. This review study revealed the AMR situation of a small area of the country and the inclusion of statistically significant number of districts in the surveillance program is recommended. Moreover, the surveillance program should include a survey on the type and amount of the antimicrobials used in different animal farming practices in Bangladesh. To explicit the emergence and distribution of the AMR pathogens in veterinary practices, laboratory-based AMR assessment in significant sample size from different farming settings is crucial. Research should address veterinary and human drug 
use, social, and economic influences on prescribing and drug-dispensing practices, traditional beliefs and local cultures, and environmental factors that promote the development of drug-resistant pathogens. The drug administration of Bangladesh should consider categorization of antimicrobials and preserve some items as prescription-only medicines. This will avoid availability or misuse of antimicrobial agents because pre-authorization or their use under supervision of infection experts will be required.

For effective monitoring, surveillance, AMR stewardship activities and awareness building on AMU and AMR, qualified manpower along with adequate funding is a prerequisite. Capacity building of veterinary hospitals and laboratories of the DLS with adequate manpower, training, logistics, and fund mobilization are crucial for successful containment of AMR in the veterinary sector of Bangladesh. However, we conclusively recommend the following measures for effective mitigation of AMR problems in veterinary practices of Bangladesh - (1) cross-sectorial policy commitment and coordination for the implementation of NAP; (2) development of the annual action plan, including national surveillance of AMR, awareness campaigns, and assessment of knowledge about AMR; (3) increasing regulatory role or law enforcement capacities of the implementing organizations; and (4) research on understanding the risk factors for the emergence and spread of AMR.

\section{Conclusion}

AMR is considered one of the most important global health issues and Bangladesh is assessed as having a high risk of AMR. The emergence and zoonotic spread of ABR bacteria or associated-resistant genes is crucial because of their existence in animal farming environment, including soil, and water, animal products and by-products. AMR is a "One Health" problem, and its rational containment warrants inclusion of the veterinary sector. Thus, the present review study was envisaged to explicit the current situation, and knowledge gaps of AMR burden in the veterinary sector of Bangladesh. In this comprehensive review of the AMR situation in veterinary practices of Bangladesh, we tried to retrieve maximum available information. Nevertheless, due to limited open data sharing policy by some of the journals and restricted access to some of the databases, the search may not be exhaustive. Therefore, this review is limited by the inclusion of a small number of articles, even though sufficiently elucidated the underlying causes of AMR emergence, current situation of AMR in veterinary practices of Bangladesh along with the weaknesses and strength of DLS to contain the problem. Hence, this review article could be used as a reference work for formulation, adoption, and implementation of a rational and pragmatic future AMR containment program in veterinary practices in Bangladesh.

\section{Authors' Contributions}

MAA: Conceptualized and designed the review. MAA and MNH: Collected the literature. MAA: Analyzed the data. MAA and MNH: Drafted the manuscript. AZS, SS, and MMK: Edited and finalized the manuscript. MMK: Acquisition of funds. All the authors read and approved the manuscript.

\section{Acknowledgments}

The authors are thankful to the "Establishment of Quality Control Laboratory for Livestock Inputs and its Food Products" project (No. 224071600), Department of Livestock Services (DLS), Government of Bangladesh, for providing necessary funds for this study.

\section{Competing of Interests}

The authors declare that they have no competing interests.

\section{Publisher's Note}

Veterinary World remains neutral with regard to jurisdictional claims in published institutional affiliation.

\section{References}

1. Hao, H., Sander, P., Iqbal, Z., Wang, Y., Cheng, G. and Yuan, Z. (2016) The risk of some veterinary antimicrobial agents on public health associated with antimicrobial resistance and their molecular basis. Front. Microbiol., 7: 1626.

2. Sharma, C., Rokana, N., Chandra, M., Singh, B.P., Gulhane, R.D., Gill, J.P.S., Ray, P., Puniya, A.K. and Panwar, H. (2018) Antimicrobial resistance: Its surveillance, impact, and alternative management strategies in dairy animals. Front. Vet. Sci., 4: 237.

3. Zellweger, R.M., Carrique-Mas, J., Limmathurotsakul, D., Day, N.P.J., Thwaites, G.E., Baker, S. and Network, S.A.A. (2017) A current perspective on antimicrobial resistance in Southeast Asia. J. Antimicrob. Chemother., 72(11): 2963-2972.

4. Rousham E.K., Unicomb, L. and Islam, M.A. (2018) Human, animal and environmental contributors to antibiotic resistance in low-resource settings: Integrating behavioural, epidemiological and one health approaches. Proc. R. Soc. B, 285(1876): 0332.

5. O'Neill, J. (2018) Tackling Drug-resistant Infections Globally: Final Report and Recommendations. 2016. HM Government and Welcome Trust: UK. Available from: https://amr-review.org/. Retrieved on 17-05-2020.

6. Orubu, E.S.F., Zaman, M.H., Rahman, M.T. and Wirtz, V.J. (2019) Veterinary antimicrobial resistance containment in Bangladesh: Evaluating the national action plan and scoping the evidence on implementation. J. Glob. Antimicrob. Resist., 21:105-115.

7. Ahmed, I., Rabbi, M.B. and Sultana, S. (2019) Antibiotic resistance in Bangladesh: A systematic review. Int. J. Infect. Dis., 80: 54-61.

8. Saifuddin, A., Isalm, S.A. and Anwar, M.N. (2016) Molecular characterization and antimicrobial resistance patterns of Salmonella spp. and Escherichia coli of laying chicken. Microb. Health, 5(1): 4-6.

9. Schar, D., Sommanustweechai, A., Laxminarayan, R. and Tangcharoensathien, V. (2018) Surveillance of antimicrobial consumption in animal production sectors of low-and middle-income countries: Optimizing use and addressing antimicrobial resistance. PLoS Med., 15(3), e1002521. 
10. Manyi-Loh, C., Mamphweli, S., Meyer, E. and Okoh, A. (2018) Antibiotic use in agriculture and its consequential resistance in environmental sources: Potential public health implications. Molecules, 23(4): 795.

11. Hernando-Amado, S., Coque, T.M., Baquero, F. and Martínez, J.L. (2019) Defining and combating antibiotic resistance from one health and global health perspectives. Natl. Microbiol., 4(9): 1432-1442.

12. DLS. (2020) Livestock Economy. Department of Livestock Services. Available from: http://www.dls.gov.bd/site/ page/22b1143b-9323-44f8-bfd8-647087828c9b/LivestockEconomy. Retrieved on 17-05-2020.

13. Roess, A.A., Winch, P.J., Akhter, A., Afroz, D., Ali, N.A., Shah, R., Begum, N., Seraji, H.R., El Arifeen, S. and Darmstadt, G.L. (2015) Household animal and human medicine use and animal husbandry practices in rural Bangladesh: Risk factors for emerging zoonotic disease and antibiotic resistance. Zoonoses Public Health, 62(7): 569-578.

14. BBS. (2020), Yearbook of Agricultural Statistics-2018. Bangladesh Bureau of Statistics. Available from: http:// www.bbs.gov.bd/site/page/3e838eb6-30a2-4709-be8540484b0c16c6/(2018). Retrieved on 17-05-2020.

15. Amin, M.B., Sraboni, A.S., Hossain, M.I., Roy, S., Mozmader, T.A.U., Unicomb, L., Rousham, E.K. and Islam, M.A. (2020) Occurrence and genetic characteristics of mcr-1 positive colistin-resistant $E$. coli from poultry environments in Bangladesh. J. Glob. Antimicrob. Resist., 22: $546-552$.

16. Alam, S.B., Mahmud, M., Akter, R., Hasan, M., Sobur, A., Nazir, K., Noreddin, A., Rahman, T., El Zowalaty, M.E. and Rahman, M. (2020) Molecular detection of multidrug-resistant Salmonella species isolated from broiler farm in Bangladesh. Pathogens, 9(3): 201.

17. Sobur, M.A., Sabuj, A.A.M., Sarker, R., Rahman, A.T., Kabir, S.L. and Rahman, M.T. (2019) Antibiotic-resistant Escherichia coli and Salmonella spp. Associated with dairy cattle and farm environment having public health significance. Vet. World, 12(7): 984.

18. Hoque, M.N., Istiaq, A., Clement, R.A., Gibson, K.M., Saha, O., Islam, O.K., Abir, R.A., Sultana, M., Siddiki, A. and Crandall, K.A. (2020) Insights into the resistome of bovine clinical mastitis microbiome, a key factor in disease complication. Front. Microbiol., 11: 860.

19. Ahmed, S., Hossain, M.I., Hossan, T., Islam, K.R., Rahman, M.B. and Hossain, M.A. (2013) The central cattle breeding and dairy farm, Bangladesh waste contributes in emergence and spread of aminoglycoside-resistant Bacteria. Adv. Biosci. Biotech., 4(2A): 278-282.

20. Hoque, R., Ahmed, S.M., Naher, N., Islam, M.A., Rousham, E.K., Islam, B.Z. and Hassan, S. (2020) Tackling antimicrobial resistance in Bangladesh: A scoping review of policy and practice in human, animal and environment sectors. PLoS One, 15(1): e0227947.

21. Neogi, S.B., Islam, M.M., Islam, S.S., Akhter, A.T., Sikder, M.M.H., Yamasaki, S. and Kabir, S.L. (2020), Risk of multidrug-resistant Campylobacter spp. and residual antimicrobials at poultry farms and live bird markets in Bangladesh. BMC Infect. Dis., 20: 1-14.

22. Momtaz, S., Saha, O., Usha, M.K., Sultana, M. and Hossain, M.A. (2018) Occurrence of pathogenic and multidrug-resistant Salmonella spp. in poultry slaughter-house in Bangladesh. Biores. Commun., 4(2): 506-515.

23. Al Masud, A., Rousham, E.K., Islam, M.A., Alam, M.U., Rahman, M., Al Mamun, A., Sarker, S., Asaduzzaman, M. and Unicomb, L. (2020) Drivers of antibiotic use in poultry production in Bangladesh: Dependencies and dynamics of a patron-client relationship. Front. Vet. Sci., 7: 78.

24. Islam, K.S., Shiraj-Um-Mahmuda, S. and Hazzaz-BinKabir, M. (2016) Antibiotic usage patterns in selected broiler farms of Bangladesh and their public health implications. J. Pubilc Health Dev. Count., 2(3): 276-284.
25. Ferdous, J., Sachi, S., Al Noman, S.Z., Hussani, Y.A.S. and Sikder, M.H. (2019) Assessing farmers' perspective on antibiotic usage and management practices in small-scale layer farms of Mymensingh district, Bangladesh. Vet. World, 12(9): 1441.

26. Khan, M., Ferdous, J., Ferdous, M., Islam, M., Rafiq, K. and Rima, U. (2018) Study on indiscriminate use of antibiotics in poultry feed and residues in broilers of Mymensingh city in Bangladesh. Prog. Agric., 29(4): 345-352.

27. Shahjada, Z., Hussain, K., Islam, M.M., Majumder, S., Hasan, I., Rahman, M. and Saha, S. (2017) Bacteria causing omphalitis in newly hatched chicks from broiler and layer flocks and their antibiotic profiles. Int. J. Natl. Soc. Sci., 4(2): 73-81.

28. Hasan, B., Faruque, R., Drobni, M., Waldenström, J., Sadique, A., Ahmed, K.U., Islam, Z., Parvez, M.H., Olsen, B. and Alam, M. (2011) High prevalence of antibiotic resistance in pathogenic Escherichia coli from largeand small-scale poultry farms in Bangladesh. Avian Dis., 55(4): 689-692.

29. Jakaria, A., Islam, M.A. and Khatun, M.M. (2012) Prevalence, characteristics and antibiogram profiles of Escherichia coli isolated from apparently healthy chickens in Mymensingh, Bangladesh. Microb. Health, 1(1): 27-29.

30. Sarker, M.S., Mannan, M.S., Ali, M.Y., Bayzid, M., Ahad, A. and Bupasha, Z.B. (2019) Antibiotic resistance of Escherichia coli isolated from broilers sold at live bird markets in Chattogram, Bangladesh. J. Adv. Vet. Anim. Res., 6(3): 272.

31. Hasan, B., Sandegren, L., Melhus, Å., Drobni, M., Hernandez, J., Waldenström, J., Alam, M. and Olsen, B. (2012) Antimicrobial drug-resistant Escherichia coli in wild birds and free-range poultry, Bangladesh. Emerg. Infect. Dis., 18(12): 2055.

32. Sultana, S., Islam, M.A., Khatun, M.M. and Nasrin, S. (2012) Multidrug-resistant Bacteria in the respiratory tract of apparently healthy quails. Microb. Health, 1(2): 46-49.

33. Dey, R.K., Khatun, M.M., Islam, M.A. and Hosain, M.S. (2013) Prevalence of multidrug-resistant Escherichia coli in pigeon in Mymensingh, Bangladesh. Microb. Health, 2(1): 5-7.

34. Parvin, M., Talukder, S., Ali, M., Chowdhury, E.H., Rahman, M. and Islam, M. (2020) Antimicrobial resistance pattern of Escherichia coli isolated from frozen chicken meat in Bangladesh. Pathogens, 9(6): 420.

35. Singh, A., Khan, M.S.R., Saha, S., Hassan, J. and Roy, U. (2012) Isolation and detection of antibiotic sensitivity pattern of Escherichia coli from ducks in Bangladesh and Nepal. Microb. Health, 1(1): 6-8.

36. Al-Salauddin, A.S., Hossain, M.F., Dutta, A., Mahmud, S., Islam, M.S., Saha, S. and Kabir, S.L. (2015) Isolation, identification, and antibiogram studies of Salmonella species and Escherichia coli from boiler meat in some selected areas of Bangladesh. Int. J. Basic Clin. Pharmacol., 4(5): 1000.

37. Dutta, A., Islam, M.Z., Barua, H., Rana, E.A., Jalal, M.S., Dhar, P.K., Das, A., Das, T., Sarma, S.M. and Biswas, S.K. (2020) Acquisition of plasmid-mediated colistin resistance gene mcr-1 in Escherichia coli of livestock origin in Bangladesh. Microb. Drug Resist., 26(9):1058-1062.

38. Mahmud, M.S., Bari, M.L. and Hossain, M.A. (2011) Prevalence of Salmonella serovars and antimicrobial resistance profiles in poultry of Savar area, Bangladesh. Foodborne Pathog. Dis., 8(10): 1111-1118.

39. Hosain, M.S., Islam, M.A., Khatun, M.M. and Dey, R.K. (2012) Prevalence and antibiogram profiles of Salmonella isolated from pigeons in Mymensingh, Bangladesh. Microb. Health, 1(2): 54-57.

40. Parvej, M.S., Nazir, K.N.H., Rahman, M.B., Jahan, M., Khan, M.F.R. and Rahman, M. (2016) Prevalence and characterization of multidrug-resistant Salmonella enterica serovar Gallinarum biovar Pullorum and Gallinarum from 
chicken. Vet. World, 9(1): 65 .

41. Nandi, S.P., Sultana, M. and Hossain, M.A. (2013) Prevalence and characterization of multidrug-resistant zoonotic Enterobacter spp. in poultry of Bangladesh. Foodborne Pathog. Dis., 10(5): 420-427.

42. Hasan, M.S., Sultana, M. and Hossain, M.A. (2019) Complete genome arrangement revealed the emergence of a poultry origin superbug Citrobacter portucalensis strain NR-12. J. Glob. Antimicrob. Resist., 18: 126-129.

43. Islam, N.N., Akter, M., Farzana, Z., Kader, A.J.B., Uddin, I., Siddiki, A. and Kamaruddin, K. (2014) Detection of Staphylococcus aureus in frozen chicken rinse through bacteriological and nuc gene-specific PCR methods and their drug resistance patterns in Southern Chittagong, Bangladesh. Res. J. Microbiol., 9(5): 251-264.

44. Kabir, S., Sumon, M., Amin, M.M. and Yamasaki, S. (2014) Isolation, identification and antimicrobial resistance patterns of Campylobacter species from broiler meat sold at KR market of Bangladesh agricultural university Campus, Mymensingh. J. Agric. Food Tech., 4(4): 15-21.

45. Siddiki, S., Samad, M., Saha, S., Badiuzzaman, M. and Islam, M. (2019) Comparison of bacterial pathogens associated with different types of bovine mastitis and their antibiotic resistance status in Bangladesh. J. Vet. Med. OH Res., 1(1): 17-27.

46. Hoque, M., Das, Z., Rahman, A., Haider, M. and Islam, M. (2018) Molecular characterization of Staphylococcus aureus strains in bovine mastitis milk in Bangladesh. Int. J. Vet. Sci. Med., 6(1): 53-60.

47. Rahman, M.T., Islam, M.S. and Hasan, M. (2013) Isolation and identification of bacterial agents causing clinical mastitis in Cattle in Mymensingh and their antibiogram Profile. Microb. Health, 2(1): 19-21.

48. Haque, M.E., Islam, M.A., Akter, S. and Saha, S. (2014) Identification, molecular detection and antibiogram profile of Bacteria isolated from California mastitis test positive milk samples of crossbred cows of Satkhira district in Bangladesh. GSTF Int. J. Vet. Sci., 1(1): 59-63.

49. Gupta, M.D., Islam, M., Sen, A., Sarker, M.S. and Das, A. (2017) Prevalence and antibiotic susceptibility pattern of
Escherichia coli in cattle on Bathan and intensive rearing system. Microb. Health, 6(1): 1-4.

50. Islam, K., Ahad, A., Barua, M., Islam, A., Chakma, S., Dorji, C., Uddin, M.A., Islam, S. and Ahasan, A.L. (2016) Isolation and epidemiology of multidrug-resistant Escherichia coli from goats in Cox s Bazar, Bangladesh. $J$. Adv. Vet. Anim. Res., 3(2): 166-172.

51. Jalal, M.S., Islam, M.Z., Dutta, A., Dhar, P.K., Das, A., Hasan, M.M., Barua, H., Biswas, P.K. and Ahad, A. (2019) Antibiotic-resistant zoonotic Bacteria in irrawaddy squirrel (Callosciurus pygerythrus). Vet. Med. Sci., 5(2): 260-268.

52. Hossain, M., Saha, S., Rahman, M., Singha, J. and Mamun, A. (2013) Isolation, identification and antibiogram study of Pseudomonas aeruginosa from cattle in Bangladesh. J. Vet. Adv., 3(7): 180-185.

53. Islam, K.I., Kabir, S.L., Saha, S. and Khan, M. (2013) Prevalence and antimicrobial resistance patterns of Vibrio cholerae from Bangladesh agricultural university dairy farm. Int. J. Med. Sci. Biotech., 1(3): 13-25.

54. Rana, E. (2017) Antibiotic resistance, microbial and morphological changes of marketed bovine liver at different time interval from Chittagong, Bangladesh: A public health Concern. Res. Rev. J. Vet. Sci., 3(1): 16-23.

55. DLS. (2020) Orgamogram. Department of Livestock Services. Available from: http://www.dls.gov.bd/site/ page/5dfbbeb3-a098-4f69-9115-8dcd4e7b1e81/-[Organogram]. Retrieved on 17-05-2020.

56. Navarro-Gonzalez, N., Porrero, M.C., Mentaberre, G., Serrano, E., Mateos, A., Domínguez, L. and Lavin, S. (2013) Antimicrobial resistance in indicator Escherichia coli isolates from free-ranging livestock and sympatric wild ungulates in a natural environment (Northeastern Spain). Appl. Environ. Microbiol., 79(19): 6184-6186.

57. Heredia, N. and García, S. (2018) Animals as sources of foodborne pathogens: A review. Anim. Nutr., 4(3): 250-255.

58. Alam, M.U., Rahman, M., Islam, M.A., Asaduzzaman, M., Sarker, S., Rousham, E. and Unicomb, L. (2019) Human exposure to antimicrobial resistance from poultry production: Assessing hygiene and waste-disposal practices in Bangladesh. Int. J. Hyg. Environ. Health, 222(8): 1068-1076.

\section{Supplementary Tables}

Table-S1: Articles $(n=5)$ reported the medication patterns in veterinary practices of Bangladesh.

\begin{tabular}{|c|c|c|c|}
\hline Author, Year & Title of the article & $\begin{array}{l}\text { Type of } \\
\text { study }\end{array}$ & Key findings \\
\hline $\begin{array}{l}\text { Roess et al., } \\
2015 \text { [13] }\end{array}$ & $\begin{array}{l}\text { Household Animal and Human } \\
\text { Medicine Use and Animal } \\
\text { Husbandry Practices in Rural } \\
\text { Bangladesh: Risk Factors for } \\
\text { Emerging Zoonotic disease and } \\
\text { antibiotic resistance }\end{array}$ & $\begin{array}{l}\text { Original } \\
\text { article }\end{array}$ & $\begin{array}{l}\text { - Rural people share houses and water bodies with animal } \\
\text { - Rural peoples seek animal healthcare from unlicensed } \\
\text { village doctors rather than formal-sector healthcare } \\
\text { providers } \\
\text { - Animal medicines, including antimicrobial drugs are being } \\
\text { used extensively in rural households of Bangladesh }\end{array}$ \\
\hline $\begin{array}{l}\text { Saiful Islam } \\
\text { et al.,' } \\
2016 \text { [24] }\end{array}$ & $\begin{array}{l}\text { Antibiotic Usage Patterns in } \\
\text { Selected Broiler Farms of } \\
\text { Bangladesh and their Public } \\
\text { Health Implications }\end{array}$ & $\begin{array}{l}\text { Research } \\
\text { article }\end{array}$ & $\begin{array}{l}\text { - } 43.8 \% \text { farmers used antibiotics for therapeutic purpose, } \\
31.5 \% \text { for prophylaxis and } 8.2 \% \text { for growth promotion } \\
\text { - }>60 \% \text { farmers used antibiotics without any prescription } \\
\text { - Residual antibiotics were detected in } 26 \% \text { of broiler meat } \\
\text { - Fluoroquinolones }(68.4 \% \text { ) were the most commonly } \\
\text { detected antibiotics }\end{array}$ \\
\hline $\begin{array}{l}\text { Khan et al., } \\
2018 \text { [26] }\end{array}$ & $\begin{array}{l}\text { Study on indiscriminate use } \\
\text { of antibiotics in poultry feed } \\
\text { and residues in broilers of } \\
\text { Mymensingh city in Bangladesh }\end{array}$ & $\begin{array}{l}\text { Research } \\
\text { article }\end{array}$ & $\begin{array}{l}\text { - } 17.5 \% \text { of the broiler sellers used antibiotics to prevent } \\
\text { unwanted mortality } \\
\text { - } 32.5 \% \text { of the sellers depended on feed sellers and } 20 \% \\
\text { on registered veterinarian for antibiotic use } \\
\text { - The highest percentages of antibiotics used in poultry } \\
\text { feed was enrofloxacin }(46.67 \%) \text {, followed by ciprofloxacin } \\
\text { ( } 30.00 \%) \text { and amoxicillin }(23.33 \%) \\
\text { - } 100 \% \text { broiler liver and } 20 \% \text { breast meat contained } \\
\text { antibiotic residues }\end{array}$ \\
\hline
\end{tabular}


Table-S1: (Continued)

\begin{tabular}{|c|c|c|c|}
\hline Author, Year & Title of the article & $\begin{array}{l}\text { Type of } \\
\text { study }\end{array}$ & Key findings \\
\hline $\begin{array}{l}\text { Ferdous et al., } \\
2019 \text { [25] }\end{array}$ & $\begin{array}{l}\text { Assessing farmers' perspective } \\
\text { on antibiotic usage and } \\
\text { management practices in } \\
\text { small-scale layer farms } \\
\text { of Mymensingh district, } \\
\text { Bangladesh }\end{array}$ & $\begin{array}{l}\text { Research } \\
\text { article }\end{array}$ & $\begin{array}{l}\text { - } 94.16 \% \text { of farmers used antibiotics without maintaining } \\
\text { the withdrawal period } \\
\text { - Farmers used ten different types of antibiotics of seven } \\
\text { classes } \\
\text { - Farmers used antibiotics of Watch group }(49 \%) \text {, Reserve } \\
\text { group }(8 \%) \text { and Las Resort group }(73 \%)\end{array}$ \\
\hline $\begin{array}{l}\text { Masud et al., } \\
2020 \text { [23] }\end{array}$ & $\begin{array}{l}\text { Drivers of Antibiotic Use } \\
\text { in Poultry Production in } \\
\text { Bangladesh: Dependencies and } \\
\text { Dynamics of a Patron-Client } \\
\text { Relationship }\end{array}$ & $\begin{array}{l}\text { Original } \\
\text { research }\end{array}$ & $\begin{array}{l}\text { - Poultry dealers provide credit and information for } \\
\text { small-scale poultry farmers to initiate and operate their } \\
\text { business } \\
\text { - Farmers are obliged to buy poultry feed and medicine } \\
\text { from their dealer } \\
\text { - All farms apply multiple antibiotics to poultry throughout } \\
\text { the production cycle, including banned antibiotics like } \\
\text { colistin sulfate } \\
\text { - Dealers are the main influencers on antibiotic use in } \\
\text { farms }\end{array}$ \\
\hline
\end{tabular}

Table-S2: Articles $(n=23)$ reported antimicrobial-resistant pathogens and genes in poultry sector of Bangladesh.

\begin{tabular}{|c|c|c|c|}
\hline Author, Year & Title of the article & Type of study & Key findings \\
\hline $\begin{array}{l}\text { Mahmud et al., } \\
2011[38]\end{array}$ & $\begin{array}{l}\text { Prevalence of Salmonella Serovars } \\
\text { and AMR Profiles in Poultry of } \\
\text { Savar Area, Bangladesh }\end{array}$ & $\begin{array}{l}\text { Research } \\
\text { article }\end{array}$ & $\begin{array}{l}\text { - The prevalence of Salmonella was recorded in } \\
21.1 \% \text { poultry farms } \\
\text { - Salmonella isolates showed resistance against } \\
5-10 \text { antibiotics }\end{array}$ \\
\hline $\begin{array}{l}\text { Hasan et al., } \\
2011[28]\end{array}$ & $\begin{array}{l}\text { High Prevalence of antibiotic } \\
\text { resistance in Pathogenic E. coli } \\
\text { from Large- and Small-Scale } \\
\text { Poultry Farms in Bangladesh }\end{array}$ & $\begin{array}{l}\text { Research } \\
\text { article }\end{array}$ & $\begin{array}{l}\text { - More than } 55 \% \text { E. coli isolates were resistant to } \\
\text { at least one or more antibiotics } \\
\text { - } 36.6 \% \text { of the isolates showed MDR }\end{array}$ \\
\hline $\begin{array}{l}\text { Hasan et al., } \\
2012[31]\end{array}$ & $\begin{array}{l}\text { Antimicrobial Drug-Resistant } \\
\text { E. coli in Wild Birds and Free- } \\
\text { range Poultry, Bangladesh }\end{array}$ & $\begin{array}{l}\text { Research } \\
\text { article }\end{array}$ & - $22.7 \%$ E. coli isolates were MDR \\
\hline $\begin{array}{l}\text { Jakaria et al., } \\
2012[29]\end{array}$ & $\begin{array}{l}\text { Prevalence, Characteristics and } \\
\text { antibiogram profiles of } \\
\text { E. coli Isolated from Apparently } \\
\text { Healthy Chickens in Mymensingh, } \\
\text { Bangladesh }\end{array}$ & $\begin{array}{l}\text { Research } \\
\text { article }\end{array}$ & $\begin{array}{l}\text { - E. coli isolates were sensitive to ciprofloxacin, } \\
\text { gentamicin and cephalexin } \\
\text { - Resistant to streptomycin, tetracycline, } \\
\text { amoxicillin, and nalidixic acid }\end{array}$ \\
\hline $\begin{array}{l}\text { Singh et al., } \\
2012[35]\end{array}$ & $\begin{array}{l}\text { Isolation and detection of } \\
\text { antibiotic sensitivity pattern of } \\
E \text {. coli from Ducks in Bangladesh } \\
\text { and Nepal }\end{array}$ & $\begin{array}{l}\text { Research } \\
\text { article }\end{array}$ & $\begin{array}{l}\text { - Isolates were highly sensitive to ciprofloxacin, } \\
\text { chloramphenicol and amoxicillin } \\
\text { - Moderately sensitive to nalidixic acid, } \\
\text { cephalexin, and co-trimoxazole } \\
\text { - Less sensitive to kanamycin }\end{array}$ \\
\hline $\begin{array}{l}\text { Hosain et al., } \\
2012[39]\end{array}$ & $\begin{array}{l}\text { Prevalence and antibiogram } \\
\text { profiles of Salmonella Isolated } \\
\text { from Pigeons in Mymensingh, } \\
\text { Bangladesh }\end{array}$ & $\begin{array}{l}\text { Research } \\
\text { article }\end{array}$ & $\begin{array}{l}\text { - } 80-90 \% \text { salmonella isolates were resistant } \\
\text { to amoxicillin, ampicillin, erythromycin, and } \\
\text { tetracycline } \\
\text { - } 60-80 \% \text { salmonella isolates were sensitive } \\
\text { to ciprofloxacin, sulfamethoxazole, } \\
\text { chloramphenicol, kanamycin, gentamicin, and } \\
\text { nalidixic acid }\end{array}$ \\
\hline $\begin{array}{l}\text { Sultana et al., } \\
2012[32]\end{array}$ & $\begin{array}{l}\text { Multidrug-resistant bacteria in } \\
\text { the respiratory tract of apparently } \\
\text { healthy quails }\end{array}$ & $\begin{array}{l}\text { Research } \\
\text { article }\end{array}$ & $\begin{array}{l}\text { - MDR E. coli, Salmonella spp., Pasteurella spp., } \\
\text { Bacillus spp., and Staphylococcus spp. were } \\
\text { identified in quails }\end{array}$ \\
\hline $\begin{array}{l}\text { Dey et al., } \\
2013[33]\end{array}$ & $\begin{array}{l}\text { Prevalence of multidrug-resistant } \\
\text { E. coli in Pigeon in Mymensingh, } \\
\text { Bangladesh }\end{array}$ & $\begin{array}{l}\text { Research } \\
\text { article }\end{array}$ & $\begin{array}{l}\text { - Pigeons are reservoir of MDR E. coli } \\
\text { - } 70-90 \% \text { E. coli is resistant to sulfamethoxazole, } \\
\text { tetracycline, and amoxicillin }\end{array}$ \\
\hline $\begin{array}{l}\text { Nandi et al., } \\
2013[41]\end{array}$ & $\begin{array}{l}\text { Prevalence and Characterization } \\
\text { of Multidrug-Resistant Zoonotic } \\
\text { Enterobacter spp. in Poultry of } \\
\text { Bangladesh }\end{array}$ & Original article & $\begin{array}{l}\text { MDR and zoonotic Enterobacter spp. are } \\
\text { prevalent in poultry farms of Bangladesh }\end{array}$ \\
\hline $\begin{array}{l}\text { Lutful Kabir } \\
\text { et al., } 2014 \text { [44] }\end{array}$ & $\begin{array}{l}\text { Isolation, Identification and AMR } \\
\text { Patterns of Campylobacter Species } \\
\text { from Broiler Meat Sold at KR } \\
\text { Market of Bangladesh Agricultural } \\
\text { University Campus, Mymensingh }\end{array}$ & $\begin{array}{l}\text { Research } \\
\text { article }\end{array}$ & $\begin{array}{l}\text { - MDR C. jejuni and C. coli are prevalent in broiler } \\
\text { meat }\end{array}$ \\
\hline
\end{tabular}


Table-S2: (Continued)

\begin{tabular}{|c|c|c|c|}
\hline Author, Year & Title of the article & Type of study & Key findings \\
\hline $\begin{array}{l}\text { Islam MN et al., } \\
2014 \text { [43] }\end{array}$ & $\begin{array}{l}\text { Detection of S. aureus in } \\
\text { Frozen Chicken Rinse through } \\
\text { Bacteriological and Nuc Gene } \\
\text { Specific PCR Methods and their } \\
\text { drug resistance Patterns in } \\
\text { Southern Chittagong, Bangladesh }\end{array}$ & $\begin{array}{l}\text { Research } \\
\text { article }\end{array}$ & $\begin{array}{l}\text { - Staphylococcus isolates showed } 100 \% \\
\text { resistance to ampicillin, more than } 80 \% \text { were } \\
\text { resistant to oxytetracycline, doxycycline, and } \\
\text { amoxicillin. Ciprofloxacin showed } 77.5 \% \text {, } \\
\text { Cephalexin } 38.33 \% \text {, and Gentamycin showed } \\
\text { the least resistance } 13.33 \%\end{array}$ \\
\hline $\begin{array}{l}\text { Al-Salauddin } \\
\text { et al., } 2015 \text { [36] }\end{array}$ & $\begin{array}{l}\text { Isolation, identification, and } \\
\text { antibiogram studies of Salmonella } \\
\text { species and } E \text {. coli from boiler } \\
\text { meat in some selected areas of } \\
\text { Bangladesh }\end{array}$ & $\begin{array}{l}\text { Research } \\
\text { article }\end{array}$ & $\begin{array}{l}\text { - Salmonella and } E \text {. coli isolates from broiler } \\
\text { meat were resistant to amoxicillin }(80-82 \%) \text {, } \\
\text { erythromycin }(82-85 \%) \text {, and tetracycline } \\
(24-68 \%)\end{array}$ \\
\hline $\begin{array}{l}\text { Saifuddin et al., } \\
2016[8]\end{array}$ & $\begin{array}{l}\text { Molecular characterization and } \\
\text { AMR patterns of Salmonella spp. } \\
\text { and E. coli of laying chicken }\end{array}$ & $\begin{array}{l}\text { Research } \\
\text { article }\end{array}$ & $\begin{array}{l}\text { - } 70-100 \% \text { of Salmonella spp. and } E \text {. coli were } \\
\text { resistant to } \beta \text {-lactam antibiotics } \\
\text { - } 60-90 \% \text { isolates of both species were } \\
\text { susceptible to ciprofloxacin and gentamicin }\end{array}$ \\
\hline $\begin{array}{l}\text { Parvej et al., } \\
2016[40]\end{array}$ & $\begin{array}{l}\text { Prevalence and characterization } \\
\text { of multidrug-resistant Salmonella } \\
\text { Enterica serovar Gallinarum biovar } \\
\text { Pullorum and Gallinarum from } \\
\text { chicken }\end{array}$ & $\begin{array}{l}\text { Research } \\
\text { article }\end{array}$ & $\begin{array}{l}\text { - MDR and highly clonal Salmonella Enterica are } \\
\text { prevalent in commercial layers of Bangladesh }\end{array}$ \\
\hline $\begin{array}{l}\text { Shahjada et al., } \\
2017 \text { [27] }\end{array}$ & $\begin{array}{l}\text { Bacteria causing omphalitis } \\
\text { in newly hatched chicks from } \\
\text { broiler and layer flocks and their } \\
\text { antibiotic profiles }\end{array}$ & $\begin{array}{l}\text { Research } \\
\text { article }\end{array}$ & $\begin{array}{l}\text { - E. coli ( } 28 \%) \text {, Salmonella spp. ( } 38 \%) \text {, } \\
\text { Staphylococcus spp. ( } 34 \%) \text { from broiler chicks } \\
\text { and E. coli }(32 \%) \text {, Salmonella spp. ( } 36 \%) \text {, } \\
\text { Staphylococcus spp. (32\%) from layer chicks } \\
\text { were identified } \\
\text { - Staphylococcus spp. were resistant to ampicillin } \\
\text { (100\%) and kanamycin }(100 \%) \text {; E. coli } \\
\text { isolates were resistant to ampicillin }(80-100 \%) \text {, } \\
\text { amoxicillin (60-100\%) and kanamycin }(80 \%) ; \\
\text { Salmonella spp. were resistant to ampicillin } \\
(100 \%), \text { kanamycin }(80 \%) \text {, and tetracycline } \\
(60 \%)\end{array}$ \\
\hline $\begin{array}{l}\text { Momtaz et al., } \\
2018[22]\end{array}$ & $\begin{array}{l}\text { Occurrence of Pathogenic and } \\
\text { Multidrug-Resistant Salmonella } \\
\text { spp. in Poultry Slaughter-House in } \\
\text { Bangladesh }\end{array}$ & Original article & $\begin{array}{l}\text { - MDR and pathogenic Salmonella spp. are } \\
\text { circulating in poultry slaughterhouses } \\
\text { - These MDR Salmonella spp. are potential threat } \\
\text { to public health }\end{array}$ \\
\hline $\begin{array}{l}\text { Sarker et al., } \\
2019 \text { [30] }\end{array}$ & $\begin{array}{l}\text { Antibiotic resistance of } E \text {. coli } \\
\text { isolated from broilers sold at LBMs } \\
\text { in Chattogram, Bangladesh }\end{array}$ & $\begin{array}{l}\text { Short } \\
\text { Communication }\end{array}$ & $\begin{array}{l}\text { - E. coli isolates were } 100 \% \text { resistant to ampicillin } \\
\text { and tetracycline } \\
\text { - All } E \text {. coli isolates carried blaTEM, tetA, and Sul2 } \\
\text { genes }\end{array}$ \\
\hline $\begin{array}{l}\text { M.S. Hasan et al., } \\
2019 \text { [42] }\end{array}$ & $\begin{array}{l}\text { Complete genome arrangement } \\
\text { revealed the emergence of a } \\
\text { poultry origin superbug } \\
\text { C. portucalensis strain NR-12 }\end{array}$ & $\begin{array}{l}\text { Short } \\
\text { Communication }\end{array}$ & $\begin{array}{l}\text { - C. portucalensis NR-12 is an emerging superbug } \\
\text { from poultry } \\
\text { - Complete genome of C. portucalensis NR-12 } \\
\text { harbored } 13 \text { acquired AMR gene markers } \\
\text { - C. portucalensis NR-12 is resistant to } 8 \text { different } \\
\text { antibiotics from six antimicrobial groups }\end{array}$ \\
\hline $\begin{array}{l}\text { Neogi et al., } \\
2020 \text { [21] }\end{array}$ & $\begin{array}{l}\text { Risk of multidrug-resistant } \\
\text { Campylobacter spp. and residual } \\
\text { antimicrobials at poultry farms } \\
\text { and LBMs in Bangladesh }\end{array}$ & $\begin{array}{l}\text { Research } \\
\text { article }\end{array}$ & $\begin{array}{l}\text { - } 49 \text { and } 42 \% \text { strains of Campylobacter spp. were } \\
\text { identified as MDR bacteria } \\
\text { - Residual antimicrobials (oxytetracycline, } \\
\text { ciprofloxacin, and enrofloxacin) were detected in } \\
\text { broiler liver and meat }\end{array}$ \\
\hline $\begin{array}{l}\text { Amin et al., } \\
2020[15]\end{array}$ & $\begin{array}{l}\text { Occurrence and genetic } \\
\text { characteristics of } m c r-1 \text { positive } \\
\text { colistin-resistant } E \text {. coli from } \\
\text { poultry environments in } \\
\text { Bangladesh }\end{array}$ & Original article & $\begin{array}{l}\text { - The emerging plasmid-mediated colistin } \\
\text { resistance gene } m c r-1 \\
\text { - All ESBL-producing } E \text {. coli carrying mcr-1 were } \\
\text { resistant to multiple classes of antibiotics }\end{array}$ \\
\hline $\begin{array}{l}\text { Shanzida et al., } \\
2020 \text { [16] }\end{array}$ & $\begin{array}{l}\text { Molecular Detection of Multidrug- } \\
\text { resistant Salmonella Species } \\
\text { Isolated from Broiler Farm in } \\
\text { Bangladesh }\end{array}$ & Original article & $\begin{array}{l}\text { - Overall prevalence of Salmonella was } 35 \% \text { in } \\
\text { broiler farms } \\
\text { - tetA, floR, bla }{ }_{\text {TEM-1' }} \text { aadA1, and intl1 genes were } \\
\text { detected in the MDR Salmonella isolates }\end{array}$ \\
\hline $\begin{array}{l}\text { Parvin et al., } \\
2020 \text { [34] }\end{array}$ & $\begin{array}{l}\text { AMR Pattern of } E \text {. coli Isolated } \\
\text { from Frozen Chicken Meat in } \\
\text { Bangladesh }\end{array}$ & Original article & $\begin{array}{l}\text { - MDR and XDR E. coli are prevalent in frozen } \\
\text { chicken sold at Super shops } \\
\text { - ESBL genes blaTEM, blaSHV and bla }{ }_{\mathrm{CTX}-\mathrm{M}-2} \text { are } \\
\text { prevalent MDR and XDR E. coli }\end{array}$ \\
\hline
\end{tabular}


Table-S2: (Continued)

\begin{tabular}{|c|c|c|c|}
\hline Author, Year & Title of the article & Type of study & Key findings \\
\hline $\begin{array}{l}\text { Dutta et al., } \\
2020 \text { [37] }\end{array}$ & $\begin{array}{l}\text { Acquisition of Plasmid-Mediated } \\
\text { Colistin Resistance Gene } m c r-1 \\
\text { in } E \text {. coli of Livestock Origin in } \\
\text { Bangladesh }\end{array}$ & $\begin{array}{l}\text { Research } \\
\text { article }\end{array}$ & $\begin{array}{l}\text { - E. coli isolated from humans, animals, } \\
\text { environment, and food samples in Bangladesh } \\
\text { was MDR ( } 70.9 \%) \\
\text { - } m c r-1 \text { gene was detected in } E \text {. coli isolates of } \\
\text { poultry source } \\
\text { - mcr-1 sequences revealed that this gene } \\
\text { evolved locally }\end{array}$ \\
\hline
\end{tabular}

$\mathrm{AMR}=$ Antimicrobial resistance, MDR=Multidrug resistance, LBMs=Live bird markets, E. coli=Escherichia coli, $\mathrm{ESBL}=$ Extended-spectrum $\beta$-lactamase, C. portucalensis=Citrobacter portucalensis, $S$. aureus=Staphylococcus aureus, C. jejuni=Campylobacter jejuni, C. coli=Campylobacter coli

Table-S3: Articles $(n=13)$ reported antimicrobial-resistant pathogens and genes in dairy and other animals of Bangladesh.

\begin{tabular}{ll}
\hline Author, Year & Title of the article \\
\hline Rahman et al., & Isolation and Identification of \\
2013 [47] & $\begin{array}{l}\text { Bacterial Agents Causing Clinical } \\
\text { Mastitis in Cattle in Mymensingh } \\
\text { and Their Antibiogram Profile }\end{array}$
\end{tabular}

Ahmed et al., The Central Cattle Breeding and 2013 [19] 2013 [52] antibiogram study of Pseudomonas aeruginosa from Cattle in Bangladesh

Islam et al., Prevalence and AMR patterns of 2013 [53] Vibrio Cholerae from Bangladesh Agricultural University dairy farm

Haque et al., 2014 [48]

Rana et al., 2016 [54]

Islam et al., 2016 [50]

Das Gupta et al., 2017 [49]

Hoque et al., 2018 [46] Marketed Bovine Liver at Different Time Interval from Chittagong, Bangladesh: A Public Health Concern

Isolation and epidemiology of multidrug-resistant $E$. coli from goats in Cox's Bazar, Bangladesh

Prevalence and antibiotic susceptibility pattern of $E$. coli in cattle on Bathan and intensive rearing system $S$. aureus strains in bovine mastitis

\section{Type of study Key findings}

Short - Staphylococcus spp. (62.5\%), Streptococcus

communication spp. (56.25\%), Bacillus spp. (37.5\%), and E. coli $(31.25 \%)$ were identified as causal agents of mastitis

- Chloramphenicol and erythromycin were found effective for the treatment of mastitis

Research article - Aminoglycoside antibiotics (Gentamycin, Kanamycin, and Streptomycin) resistant bacteria are spreading from dairy farm and veterinary clinics to environment

Original article

- Pseudomonas aeruginosa isolates were resistant to ampicillin, oxytetracycline, tetracycline, and amoxicillin

Research article - All of the $V$. cholerae isolates milk, water, and feces of dairy farm were found MDR

- MDR V. cholerae isolates were resistant to erythromycin (95.23), azithromycin (76.9\%), and ampicillin (52.38\%)

Research article - S. aureus (49.09\%), followed by E. coli (27.27\%), coagulase-negative Staphylococcus (CNS) spp. (18.18\%) and Bacillus spp. (5.45\%) were responsible for mastitis

- S. aureus isolates were found resistant to 5 antibiotics and E. coli to 9 antibiotics

- E. coli isolates were completely resistant to ampicillin (100\%) and amoxicillin (100\%)

Research article - Bovine livers sold at retail meat shops are contaminated with high extent of MDR bacteria

and Morphological Changes of

Original article

- Overall prevalence of $E$. coli in the rectal swabs of goats was $52 \%$

- Among the E. coli isolates, $39.74 \%$ were resistant to 3-8 subclasses of antibiotics

Research article - The prevalence of $E$. coli was significantly high in cattle under intensive farming than cattle on Bathan

- Antibiotic-resistant $E$. coli isolates are present in cattle of different management systems

Molecular characterization of Research article milk in Bangladesh
- S. aureus isolates from bovine subclinical mastitis milk showed highest resistance to oxytetracycline $(74.5 \%)$, followed by oxacillin $(55.9 \%)$, ciprofloxacin $(49.6 \%)$, amoxicillin $(42.0 \%)$, trimethoprim/sulfamethoxazole $(30.0 \%)$, and to a less extent to gentamicin $(17.9 \%)$, penicillin $(11.0 \%)$, and erythromycin $(8.2 \%)$ 
Table-S3: (Continued)

\begin{tabular}{|c|c|c|c|}
\hline Author, Year & Title of the article & Type of study & Key findings \\
\hline $\begin{array}{l}\text { Sobur et al., } \\
2019 \text { [17] }\end{array}$ & $\begin{array}{l}\text { Antibiotic-resistant } E \text {. coli and } \\
\text { Salmonella spp. associated with } \\
\text { dairy cattle and farm environment } \\
\text { having public health significance }\end{array}$ & Research article & $\begin{array}{l}\text { - Dairy farm and their environmental components } \\
\text { carry antibiotic-resistant pathogenic E. coli and } \\
\text { Salmonella spp. }\end{array}$ \\
\hline $\begin{array}{l}\text { Jalal et al., } \\
2019 \text { [51] }\end{array}$ & $\begin{array}{l}\text { ABR zoonotic bacteria in Irrawaddy } \\
\text { squirrel (Callosciurus pygerythrus) }\end{array}$ & Original article & $\begin{array}{l}\text { - Irrawaddy squirrels harbor several types of } \\
\text { zoonotic pathogenic AMR bacteria }\end{array}$ \\
\hline $\begin{array}{l}\text { Siddiki et al., } \\
2019 \text { [45] }\end{array}$ & $\begin{array}{l}\text { Comparison of Bacterial Pathogens } \\
\text { Associated with Different Types of } \\
\text { Bovine Mastitis and their antibiotic } \\
\text { resistance Status in Bangladesh }\end{array}$ & Original article & $\begin{array}{l}\text { - Staphylococcus spp., Streptococcus spp., } \\
\text { Bacillus spp., and E. coli are associated in } \\
78.54 \%, 80 \% \text {, and } 71.67 \% \text { mastitis cases as } \\
\text { a single and in } 21.46 \%, 20 \% \text {, and } 28.33 \% \text { as } \\
\text { mixed infection, respectively } \\
\text { - The isolates were resistant to streptomycin (70- } \\
100 \%) \text {, amoxicillin (30-100\%), and ampicillin } \\
(100 \%)\end{array}$ \\
\hline $\begin{array}{l}\text { Hoque et al., } \\
2020[18]\end{array}$ & $\begin{array}{l}\text { Insights into the Resistome } \\
\text { of Bovine Clinical Mastitis } \\
\text { Microbiome, a Key Factor in } \\
\text { Disease Complication }\end{array}$ & Original research & $\begin{array}{l}\text { - } 76.2 \% \text { of six selected pathogens were highly } \\
\text { resistant to tetracycline, doxycycline, nalidixic } \\
\text { acid, ampicillin, and chloramphenicol } \\
\text { - Among the RATC functional groups, MDR to } \\
\text { efflux pumps (MREP, } 28.6 \%) \text {, CmeABC operon } \\
(8.9 \%) \text {, resistance to fluoroquinolones (RFL, } \\
6.2 \%) \text {, mdtABCD cluster (5.5\%), methicillin } \\
\text { resistance in Staphylococci (MRS, 3.8\%), } \\
\text { BlaR1 regulatory family (BlaR1, 3.4\%), } \\
\text { MexE-MexFOprN ( } 2.4 \%) \text {, and beta-lactamase } \\
\text { resistance (BLAC, } 2.2 \% \text { ) were the dominating } \\
\text { ARGs found in CM milk microbiomes }\end{array}$ \\
\hline
\end{tabular}

$\mathrm{AMR}=$ Antimicrobial resistance, $\mathrm{MDR}=$ Multidrug resistance, $\mathrm{ARGs}=$ Antibiotic resistance genes, $E$. coli=Escherichia coli, $S$. aureus $=$ Staphylococcus aureus, $A B R=$ Antibiotic-resistant

Table-S4: Articles $(n=3)$ described institutional and policy structure of the DLS of Bangladesh.

\begin{tabular}{|c|c|c|c|}
\hline Author, Year & Title of the article & $\begin{array}{l}\text { Type of } \\
\text { study }\end{array}$ & Key findings \\
\hline $\begin{array}{l}\text { Zellweger et al., } \\
2017 \text { [3] }\end{array}$ & $\begin{array}{l}\text { A current perspective on AMR in } \\
\text { Southeast Asia }\end{array}$ & Review & $\begin{array}{l}\text { - Multiple drivers along with loosely regulated } \\
\text { access to antimicrobials are responsible for AMR } \\
\text { development in the region }\end{array}$ \\
\hline $\begin{array}{l}\text { Samuel et al., } \\
2019[6]\end{array}$ & $\begin{array}{l}\text { Veterinary AMR containment in } \\
\text { Bangladesh: Evaluating the NAP } \\
\text { and scoping the evidence on } \\
\text { implementation }\end{array}$ & Review & $\begin{array}{l}\text { - Policy gaps, including an explicit financing modality } \\
\text { and specifications for antimicrobial stewardship } \\
\text { (AMS) exist in the veterinary sector } \\
\text { - Rigorous operational, monitoring and evaluation } \\
\text { frameworks weakness in veterinary sector }\end{array}$ \\
\hline $\begin{array}{l}\text { Hoque R et al., } \\
2020[20]\end{array}$ & $\begin{array}{l}\text { Tackling AMR in Bangladesh: } \\
\text { A scoping review of policy and } \\
\text { practice in human, animal and } \\
\text { environment sectors }\end{array}$ & $\begin{array}{l}\text { Research } \\
\text { article }\end{array}$ & $\begin{array}{l}\text { - Bangladesh has developed NAP for containment of } \\
\text { AMR } \\
\text { - Lack of functional mechanism for implementation } \\
\text { or coordination, lack of adequate financial, and } \\
\text { institutional resources for relevant capacity, and } \\
\text { means for infection prevention and control and } \\
\text { building awareness and political commitment are the } \\
\text { barriers to implement NAP }\end{array}$ \\
\hline
\end{tabular}

AMR=Antimicrobial resistance, NAP=National action plan, DLS=Department of Livestock Services 